\title{
REFLEKSI FILOSOFIS ATAS PENGEMBANGAN CIVIC VALUES MELALUI PEMBERDAYAAN EKONOMI MASYARAKAT BERSAMA PESANTREN
}

\author{
Alim Roswantoro \\ Universitas Islam Negeri Sunan Kalijaga Yogyakarta \\ Email: alimroswa@yahoo.com
}

\section{Abstract}

The article is the philosophical reflection on the result of the qualitative research of the two pesantren in Java, i.e., Pesantren Tarbiyatun Nasyi' in Paculgowang Jombang at East Java and Pesantren Al-Hikmah Karangmojo at Gunung Kidul Yogyakarta. The two pesantren were chosen because they have gotten the empowering training from one of the centers of Sunan Kalijaga State Islamic University. The main target of the training is to develop civic values, that is, democracy, pluralism and gender equality in pesantren and the surrounding society through the acitivities of economic empowerment of society in cooperation with pesantren. The article tries to explore and find out the results of the empowerment of the two pesantrens, and then tries to reflect them philosophically. And the main result is that the pesantrens and the surrounding peoples can accept the importance of the values of democracy, pluralism, and woman-man equality easier through the real economic activities rather than through discussion on those values in the Islamic perspective. The article can philosophically reflects that the endeavor to change the peoples' mindset will become nothing if we do not give them the basic need for being able to survive economically. The welfare equality lead them to easily understand what the value of mutual respect making all people free.

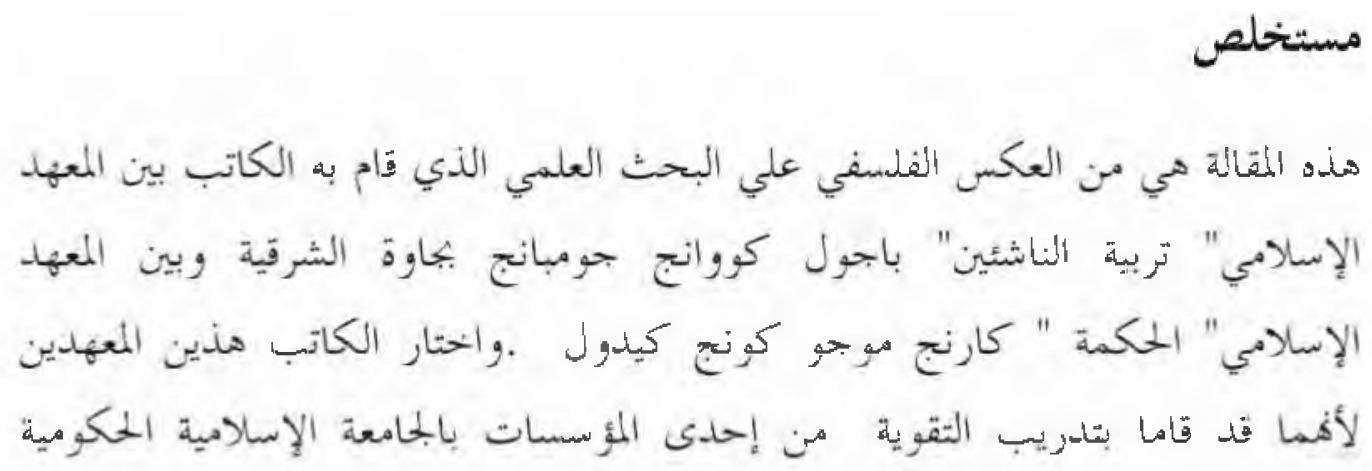




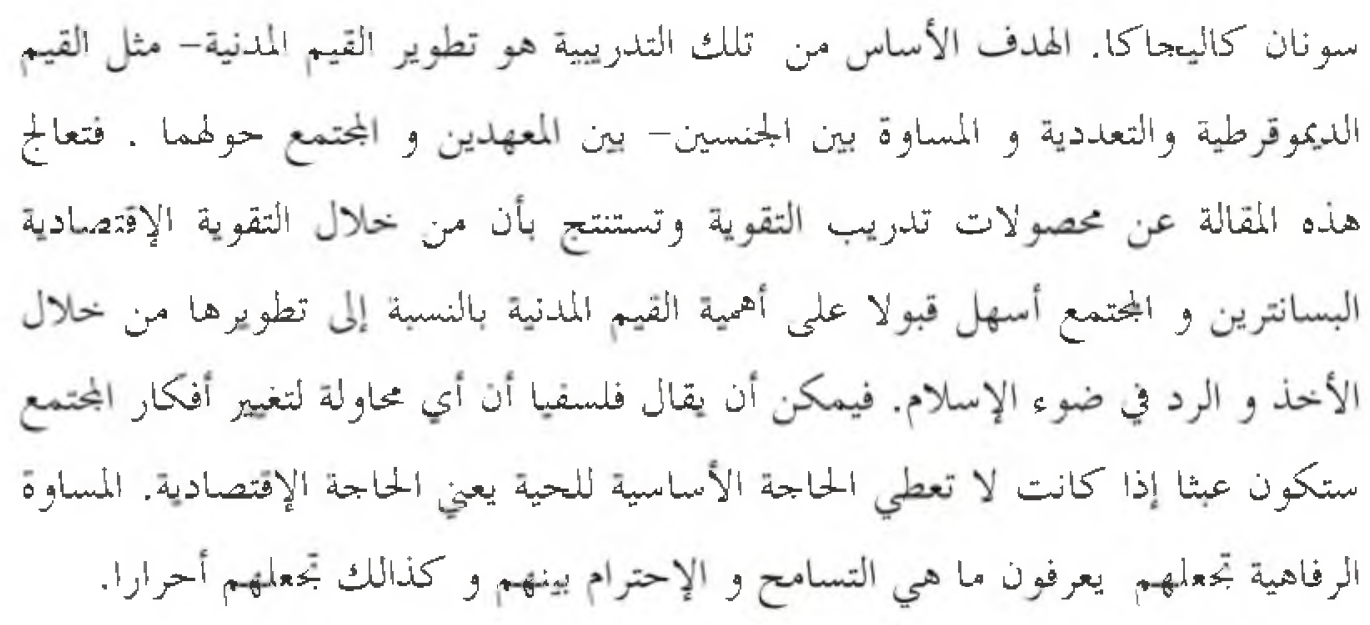

Keywords: Civic Values, Pemberdayaan Ekonomi, Masyarakat Pesantren, dan Refleksi Filosofis

\section{A. Pendahuluan}

Kemiskinan ${ }^{1}$ di Indonesia seolah menjadi masalah yang tak kunjung reda. Hal ini terjadi karena selama ini banyak konsep pembangunan yang dikembangkan menemui hasil yang jauh dari harapan, karena memisahkan pembangunan ekonomi dari pembangunan sosial. Sektor-sektor yang selama ini dikelompokkan dalam bidang sosial seperti pendidikan dan kesehatan, menjadi terabaikan dan terkalahkan oleh sektor-sektor dalam kelompok ekonomi. Dalam sistem pembangunan nasional, kategori pembanguna ekonomi yang terpisah dengan pembangunan sosial itu diikuti, sehingga sektor-sektor sosial kurang diperhatikan. ${ }^{2}$ Berbicara tentang pemecahan masyarakat miskin di Indonesia, maka pelibatan masyarakat sebagai agen penggerak ekonomi masyarakat pedesaan sekitarnya menjadi penting dijadikan target untuk percepatan pengentasan kemiskinan. Dalam konteks kelembagaan di daerah pedesaan, pesantren

1 Edi Suharto menyebut penyebab kemiskinan setidaknya ada tujuh faktor. Ketujuh faktor tersebut adalah, pertama, kecacatan yang dialami oleh manusia, kedua, tingkat pendidikan yang rendah, ketiga, ketiadaan modal dan keterampilan berusaha, keempat, ketaktersediaan kesempatan kerja, kelima, pemutusan hubungan kerja (PHK), keenam, ketiadaan jaminan sosial seperti pensiun dan kesehatan, dan ketujuh, lokasi hidup di tempat yang sangat sepi dan terpencil dengan sumber daya alam dan infrastruktur yang terbatas. Edi Suharto, Membangun Masyarakat, Memberdayakan Rakyat, Kajian Strategis Pembangunan Kesejahteraan Sosial dan Pekerja Sosial (Bandung: Refika Aditama, 2005), hal. 131

2 Agnes Sunartiningsih, Pemberdayaan Masyarakat Desa Melalui Institusi Lokal (Yogyakarta: Aditya Media Bekerjasama dengan Jurusan Sosiatri Fisipol UGM, 2004), hal. 49. 
sebenarnya mempunyai peran penting, sebab mayoritas pesantren berada di pedesaan. Bila pesantren bisa digerakkan untuk turut serta dalam kegiatan ekonomi dan ditangani secara sungguh-sungguh dan serius, maka tidak mustahil akan muncul kekuatan baru dari pelaku ekonomi di masyarakat Indonesia. ${ }^{3}$

Dengan berasumsi bahwa pembangunan ekonomi yang terintegrasi dengan pembangunan sosial-keagamaan, suatu Lembaga di Yogyakarta, Pusat Kajian Dinamika Agama, Masyarakat, dan Budaya (Puskadiabuma) Pascasarjana UIN Sunan Kalijaga pada tahun 2008-2009, tertarik melakukan suatu pemberdayaan ekonomi masyarakat dengan menempatkan pesantren sebagai institusi sosial sebagai motor penggerak ekonomi masyarakat sekitarnya berbasis pengembangan civic values yang difokuskan pada tiga nilai, nilai pluralisme, demokrasi, dan kesetaraan yang berkeadilan antara perempuan dan laki-laki. Pemberdayaan ini dilakukan di sepuluh pesantren di Jawa, yang dua di antaranya adalah Pesantren Tarbiyatun Nasyi'in Tawangsari Paculgowang Jombang, dan satunya lagi di Yogyakarta, yaitu Pesantren Al-Hikmah Sumberejo Gunung Kidul. ${ }^{4}$

3 Departemen Agama RI. Lihat Departemen RI, Data Potensi Pondok Pesantren Seluruh Indonesiaa Tahun 1997 (Jakarta: Departemen Agama RI, 1997), Daftar Pondok Pesantren Seluruh Indonesia Tahun 2003-2004 (Jakarta: Departemen Agama RI, 2004), seperti dikutip Jajat Burhanuddin, Islamic Knowledge, Authority and PoliticalPower: The Ulama in Colonial Indonesia Ph.D Dissertation (Leiden: Universiteit Leiden, 2007), hal. 2. Pesantren telah banyak mendapatkan perhatian sejak tahun 1970. Lembaga-lembaga seperti Lembaga Penelitian, Pendidikan, dan Penerangan Ekonomi dan Sosial (LP3ES). Friedrich Nauan Stiftung (FNS), sebuah LSM dari Jerman yang banyak membantu pengembangan pesantren mulai tahun 1980-an, dan Perhimpunan Pengembangan Pesantren dan Masyarakat (P3M) mulai tahun 1983 tertarik dalam mengembangkan pesantren dan pengembangan masyarakatnya termasuk sektor ketrampilan dan ekonomi. Lihat, Dawam Raharjo (ed.), Pergulatan Dunia Pesantren: Membangun dari Bawah (Jakarta: P3M, 1985), hal. xiii-xvi, juga Jajat Burhanuddin, Hendro Prasetyo, dkk, Civic Values di Indonesia Pengalaman Pemberdayaan Pesantren (Jakarta: PPIM UIN Syarif Hidayatullah Jakarta, 2009), hal. 74-77.

4 Ketertarikan ini ditawarkan kepada The Asia Foundation (TAF) Jakarta yang mempercayakan Project selama dua tahun, menindaklajuti Project 3 tahun sebelumnya yang telah dilakukan secara konsorsium antara Puskadiabuma Pascasarjana UIN Sunan Kalijaga Yogyakarta dan Pusat Pengkajian Islam dan Masyarakat (PPIM) UIN Syarif Hidayatullah Jakarta di bawah funding yang sama yaitu Danida Kedutaan Besar Denmark Indonesia. Sebelumnya Puskadiabuma telah juga mengadakan kegiatan di pesantren di Jawa, Sumatra, dan Nusa Tenggara Barat bersama PPIM UIN Syarif Hidayatullah Jakarta pada tahun 2005-2007. Kegiatan yang dilakukan pelatihan mengenai kaitan Islam pesantren dan pengembangan civic values. Tetapi, karena pendekatannnya adalah pemikiran dan wacana, hasilnya tidak begitu menggembirakan dan tidak terkait dengan masalah ekonomi sama sekali. Pada kesempatan kedua, untuk kegiatan tahun 2008-2009, Puskadiabuma mengubah paradigma pengambangan civic values melalui pengembangan ekonomi masyarakat dengan motor penggeraknya pesantren. Hasilnya ternyata lebih menggembirakan. 
Penting untuk dilihat dalam kenyataannya untuk mencari bukti signifikansi peran pesantren dalam pengentasan kemiskinan masyarakat yang tinggal pedesaan di mana pesantren itu berada. Penelitian ini ingin menjawab persoalan berikut, pertama, bagaimana hasil-hasil yang bisa didapatkan dari kegiatan pengembangan civic values, yaitu nilai-nilai demokrasi, pluralisme, dan kesetaraan gender melalui pemberdayaan ekonomi di kedua pesantren tersebut dan apa kontribusinya bagi pengembangan kebijakan pengentasan kemiskinan di Indonesia.; kedua, nilai-nilai filosofis seperti apakah yang bisa direfleksikan dari hasil-hasil tersebut.

Untuk menjawab masalah tersebut, kerangka teori yang diurai berikut dipakai. Pengembangan masyarakat bisa memiliki dua model, yaitu pengembangan masyarakat dengan paradigma atas-ke-bawah (top-down paradigm of community development) dan pembangunan atau pengembangan masyarakat dengan paradigma bawah-ke-atas (buttom-up paradigm of community development). Wrihatnolo dan Dwidjowijoto menyebut paradigma yang kedua tersebut dengan pengembangan berbasis masyarakat (community based development), yang selanjutnya, secara berkelanjutan, ia dikendalikan dan diarahkan oleh masyarakat (community driven development). ${ }^{5}$

Potensi ekonomi Indonesia sebenarnya kuat pada ekonomi kerakyatan, yaitu kegiatan ekonomi rakyat banyak. Pengertian ini mengacu pada kegiatan ekonomi yang dilakukan oleh rakyat banyak dengan skala-skala kecil. Diakui atau tidak sesungguhnya ekonomi Indonesia sudah berpihak pada sistem ekonomi kapitalis. Pemilik modal lebih dihargai dari pada mereka yang modalnya sedikit. Pelaku ekonomi bermodal besar dilihat dari sisi jumlah sangat kecil $(0,02 \%)$ dibanding pelaku ekonomi kecil dan menengah (99,98\%). Berbagai kajian menemukan bahwa salah satu faktor kunci yang menyebabkan perekonomian Indonesia mengalami goncangan hebat adalah ketergantungannya pada pengusaha konglomerat namun secara internal perusahaannya tidak sehat. ${ }^{6}$ Dengan kenyataan ini, maka orientasi kebijakan ekonomi perlu diubah, dari ekonomi kapitalis menjadi ekonomi kerakyatan.

5 Randi R. Wrihatnolo dan Riant Nugroho Dwidjowijoto, Manajemen Pemberdayaan - sebuah Pengantar dan Panduan untuk Pemberdayaan Masyarakat (Jakarta: Alec Media Komputindo, 2007), hal. 74-75. Pemberdayaan masyarakat merupakan upaya mendorong untuk berubah kelompok masyarakat rentan dan lemah sampai ia memiliki kemampuan dalam memenuhi kebutuhan dasarnya, menjangkau sumber-sumber produktif yang memungkinkan mereka dapat meningkatkan pendapatannya dan berpartisipasi dalam proses pembangunan dan keputusan-keputusan yang mempengaruhi mereka. Edi Suharto, Membangun Masyarakat, Memberdayakan Rakyat, Kajian Strategis Pembangunan Kesejahteraan Sosial dan Pekerja Sosial (Bandung: Refika Aditama, 2005), hal. 58.

6 Bayu Krisnamukthi, "Ekonomi Kerakyatan dalam Pembangunan Ekonomi Indonesia" dalam Jumal Ekonomi Rakyat No 3, Mei 2002. 
Artikel ini berusaha menjawab dua pertanyaan tersebut dengan melakukan riset kualitaif ${ }^{7}$ atas pemberdayaan yang terjadi di dua pesantren target. Teknik purposive sampling ${ }^{8}$ dipakai dan pengumpulan data melalui observasi, ${ }^{9}$ dokumentasi, ${ }^{10}$ dan wawancara. ${ }^{11}$ Analisis penelitian menggunakan pendekatan fenomenologis dan filosofis.

B. Civic Values

Terkait dengan pemberdayaan ekonomi masyarakat pesantren, terdapat tiga pengertian. Pertama, pemberdayaan ekonomi masyarakat pesantren dapat berarti pemberdayaan ekonomi pesantren itu sendiri secara internal. Kedua, pemberdayaan ekonomi masyarakat yang ada di sekitar pesantren. Ini berarti pemberdayaan ekonomi masyarakat bawah tempat pesantren berada. Ketiga, pemberdayaan ekonomi masyarakat bersama pesantren. Ini berarti pesantren berperan aktif sebagai agent of change yang berupaya mengubah kondisi ekonomi masyarakat sekitarnya.

Tulisan ini lebih fokus pada pengertian ketiga. Secara khusus pemberdayaan ekonomi ini dikaitkan dengan upaya mendiseminasikan nilai-nilai keadaban dan kewargaan (civic values) melalui sektor ekonomi seperti pemberdayaan perempuan, penghargaan terhadap orang lain, keadilan, dan tentu saja kesejahteraan masyarakat;

7 Penelitian kualitatif, seperti dinukil oleh Moleong, menurut Kirk dan Miller, merupakan tradisi dalam ilmu sosial yang secara mendasar bergantung pada pengamatan manusia dalam kawasannya sendiri dan berhubungan dengan orang-orang tersebut dalam bahasanya dan dalam peristilahannya, dan menurut Jane Richie, merupakan upaya untuk menyajikan dunia sosial dan perspektifnya di dalam dunia dari segi konsep, perilaku, persepsi, dan persoalan tentang manusia yang diteliti. Lexi J. Moleong, Metodologi Penelitian Kualitatif, Edisi Revisi (Bandung: Remaja Rosdakarya, 2009), hal. 2 dan 6.

8 Sugiyono, Metode Penelitian Kualitatif dan $R \& D$ (Bandung: Alfabet, 2010), hal. 219.

9 Teknik observasi yang dipakai adalah observasi tidak terstruktur, yaitu observasi yang tidak dipersiapkan secara sistematis tentang apa yang akan diamati, melainkan peneliti melakukan pengamatan bebas dan melakukan analisis, kemudian membuat kesimpulan. Fokus pengamatan berkembang selama kegiatan pengamatan berlangsung. Lihat Lexi J. Moleong, Metodologi Penelitian Kualitatif, hal. 228.

${ }^{10}$ Dokumentasi adalah metode pengumpulan bahan-bahan penelitian dalam bentuk dokumen yang relevan dengan tema dan topik penelitian, yang bisa berupa buku-buku, karya ilmiah dalam jurnal akademik, data-data profil kelembagaan, dan data-data tertulis lainnya baik yang dipublikasikan maupun tidak dipublikasikan.Sutrisno Hadi, Metodologi Penelitian (Yogyakarta: Andi Offset, 2000), hal. 2.

11 Wawancara yang dimaksudkan di sini adalah metode pengumpulan data dengan cara tanyatawab antara peneliti dan informan yang dikerjakan secara sistematik dan berlandaskan tujuan penelitian. Suharsimi Arikunto, Prosedur Penelitian Suatu Pendekatan Praktek (1998), hal. 135 
nilai-nilai ini terangkum dalam tiga nilai dalam civic values, seperti telah disebut sebelumnya, yaitu pluralisme atau nilai kemajemukan, demokrasi, dan gender atau kesetaraan antara perempuan dan laki-laki.

Civic values secara etimologis berasal dari kata value yang artinya nilai, dan civic bisa berarti warga atau warga negara. Secara istilah, civic values adalah "the principles that guide both the government and the public life of the people." 12 Berbicara tentang civic values atau nilai-nilai kewargaan berarti pada dasarnya berbicara tentang kehidupan manusia sebagai anggota masyarakat. Dengan kata lain, ketika berbicara tentang nilai-nilai kewargaan, berarti juga berbicara mengenai kehidupan dalam ruang yang lebih sempit, yaitu kehidupan tentang warga: apa artinya menjadi warga suatu masyarakat, bagaimana seharusnya seorang warga bersikap dan berperilaku di tengah-tengah komunitasnya, mengapa setiap orang mesti menjadi warga suatu masyarakat tertentu dan bagaimana hubungannya dengan orang-orang lain yang menjadi warga dari masyarakat-masyarakat selainnya. ${ }^{13}$ Dalam kehidupan sosial politik masyarakat manusia, civic values memang menjadi pilar penguatan civil society. Civil society bisa dicirikan oleh ruang publik yang bebas, demokratis, pluralis, toleran, keadilan sosial, dan berkeadapan. ${ }^{14}$

Istilah civic values dalam konteks tulisan ini mengacu pada nilai-nilai keadaban antar manusia yang satu dengan yang lainnya dengan berbagai perbedaan latar belakang yang menyertainya. Dalam riset ini, dipandang penting menekankan nilai penghormatan atas kemajemukan orang (pluralisme), nilai pelibatan dan partisipasi

12 Lihat Machasin, "Respon Pesantren terhadap Civic Values, makalah dipresentasikan dalam Public Hearing Pengembangan Pesantren, Hotel Sahid Yogyakarta, 31Mei -1 Juni 2005: hal. 2-3.

13 Alim Roswantoro, "Civic Values: Membangun Visi Warga dan Kewargaan Menuju Masyarakat Madani, Perspektif Filsafat Sosial” dalam Jurnal Pemikiran Filsafat dan Pemikiran Keislaman Refleksi, vol. 5 No. 2 Juli 2005: hal. 101

14 Ubaidillah dkk, Pendidikan Kewargaan (Civic Education) Demokrasi, HAM, \& Masyarakat Madani (Jakarta: IAIN Syarif Hidayatullah Press, 2000), hal. 147. Syafi’i Ma' arif menggarisbawahi ada empat ciri civil society, yaitu justice-oriented, egalitarianisme, toleransi dan keterbukaan. Lihat Syafi'i Ma'arif, "Universalisme Nilai-nilai Politik Islam menuju Masyarakat Madani," Profetika Jurnal Studi Islam, vol. I, No. 2 Juli 1999: hal. 172. Ciri-ciri itu memang juga melekat pada model masyarakat yang banyak diperbincangkan oleh kaum muslim, yakni Masyarakat Madani. Tujuan utama dan dasarnya pun sama yakni pemanusiaan manusia, namun belum tentu sama paradigmanya. Sepakat dengan Nurcholish Madjid bahwa jauh sebelum Barat mengenal dan mempraktikkan civil society, Nabi Muhammad SAW. sudah menerapkannya di Madinah. Lihat Akram Diya' al-'Umari, Madinah Society at the Time of the Prophet, trans. Huda Khattab (USA: The International Institute of Islamic Thought, 1995), hal. 79; lihat juga Munawir Syadzali, Islam dan Tata Negara, Ajaran, Sejarah, dan Pemikiran (Jakarta: UI Press, 1993), hal. $10-15$. 
setiap anggota masyarakat (demokrasi), dan nilai kesetaraan-berkeadilan antara perempuan dan laki-laki (gender) dalam pemberdayaan ekonomi masyarakat yang digerakkan oleh pesantren.

John Courtney Murray menyatakan bahwa pluralisme adalah kelompokkelompok orang dengan perbedaan-perbedaan, bahkan pertentangan-pertentangan, pandangan dan identitas yang hidup dalam suatu komunitas sosial-politik, yang karena perbedaan-perbedaan dan pertentangan-pertentangan itu harus dihargai sebagai kekayaan perspektif, maka di dalam komunitas tersebut harus juga terkandung suatu kesepakatan atau konsensus bersama di antara mereka. ${ }^{15}$

Dalam hal agama-agama, pluralisme agama adalah suatu paham yang mengakui keragaman atau kemajemukan agama, yang tidak benar bila diartikan menyamakan semua agama. Ia lebih menunjukkan bahwa realitas agama adalah berbeda-beda yang harus disikapi secara terbuka dari sisi kemanusiaannya, yaitu bahwa setiap manusia memiliki kebebasan untuk menentukan dan memilih suatu agama sebagai keyakinannya. ${ }^{16}$

Dari pemahaman yang baik atas pluralisme yang berupa fakta keragaman realitas apakah itu bahasa, etnis, budaya, pandangan hidup, kepentingan sosial-politik, maupun agama, secara ekonomi, orang bisa menempatkannya sebagai modal sosial untuk melakukan kegiatan-kegiatan dan pengembangan-pengembangan ekonomi. Keuntungan dari sikap penempatan pluralisme sebagai modal sosial ekonomi ini tidak hanya ada pada sisi produksi ekonomi, tetapi juga pada sisi pemasarannya. Pemanfaatan keahlian-ketrampilan dari dan kerjasama dengan pihak-pihak yang plural dalam latarbelakang pendidikan, kesukuan, kebangsaan, keagamaan, dan keberimanan akan mengefektif-efisienkan produksi ekonomi dan juga pemasaran hasil ekonominya.

Kekuasaan dalam demokrasi adalah kekuasaan yang dihasilkan dari kehendak semua warga komunitas melalui pemberian keterbukaan untuk berpartisipasi memberikan pandangan kepada setiap warga tanpa melihat status dan latar belakangnya dengan tujuan suatu kesepakatan bersama. Dengan pelibatan dan pembukaan partisipasi semua warga yang dijamin oleh kekuasaan, suatu komunitas,

15 John Courtney Murray, We Hold These Truth (New york: Sheed \& Ward, 1960), hal. x

16 Subur Tjahjono dan Imam Prihadiyoko, "M. Syafi'I dan Obsesi Pluralisme” hasil wawancara dengan M. Syafi'I Anwar, Direktur Eksekutif International Centre for Islam and Pluralism (ICIP), dalam Harian Kompas, Sabtu, 30 Juli 2005, hal. 5; lihat juga A. Mukti Ali, "Ilmu Perbandingan Agama, Dialog, Dakwah, dan Misi” dalam Burhanuddin Daja dan Herman Leonard Beck (eds.), Ilmu Perbandingan Agama di Indonesia dan Belanda (Jakarta: INIS, 1992), hal. 230. 
atau organisasi, atau negara dan seterusnya bermaksud menciptakan suatu keadilan sosial, kesejahteraan, keamanan, dan pengondisian kebebasan bagi seluruh warga, tanpa melihat "kotak-kotak" perbedaan-perbedaan yang ada.

Dalam konteks pembangunan ekonomi masyarakat berbasis pesantren, pesantren berarti sebagai penggerak masyarakat sekitarnya untuk mencari potensi ekonomi yang mungkin bisa dikembangkan untuk kepentingan bersama dan demi kemajuan bersama. Dalam menjalankan rencana usaha-usaha ekonomi kerakyatan, pesantren membuka partisipasi semua elemen masyarakat sekitarnya untuk memberikan suara dan pandangannya tentang peluang usaha ekonomi apa yang mungkin bisa diberdayakan dan sekaligus strategi pengembangannya untuk tujuan peningkatan kesejahteraan masyarakat dan pesantren.

Dalam kegiatan usaha ekonomi, pesantren juga harus menawarkan kepada sebanyak mungkin warga yang bisa dan memiliki kemampuan untuk keberhasilan usaha ekonomi masyarakat. Partisipasi dibuka juga mempertimbangkan keterlibatan laki-laki dan perempuan. Karena usaha ekonomi merupakan bagian urusan-urusan sosial, maka perempuan harus juga diakses dan didorong untuk bisa terlibat, karena dalam urusan-urusan sosial perlakuan setara-berkeadilan antara laki-laki dan perempuan harus dilakukan. Perbedaan jenis kelamin (sex differences) itu pada umumnya melahirkan perbedaan gender (gender differences) dalam masyarakat. Perbedaan gender (gender differences) sebenarnya tidaklah menjadi persoalan sepanjang tidak melahirkan ketidakadilan gender (gender inequalities). Namun yang menjadi masalah ternyata perbedaan gender telah melahirkan berbagai ketidakadilan, baik terhadap kaum laki-laki dan terutama terhadap kaum perempuan. Ketidakadilan gender termanifestasikan dalam berbagai bentuk ketidakadilan, yaitu: pembentukan stereotipi, subordinasi, marginalisasi, beban kerja lebih panjang dan lebih banyak (double burden), kekerasan serta sosialisasi ideologi nilai peran gender. ${ }^{17}$ Manifestasi ketidakadilan gender ini seringkali hadir dalam keyakinan masing-masing orang, keluarga hingga pada tingkat negara dan politik global. Di wilayah inilah sangat perlu dimasukkan perspektif keadilan gender. ${ }^{18}$

Gender sebagai sebuah perspektif untuk memandang kenyataan adalah berbagai asumsi dasar, model, konsep serta metode yang digunakan untuk mengungkapkan

17 Mansour Fakih, Analisis Gender dan Transformasi Sosial (Yogyakarta: Pustaka Pelajar, 1999), hal. 12.

18 Alim Roswantoro dan Mochamad Sodik, Nilai-nilai Masyarakat Madani dalam Pemberdayaan Ekonomi (Yogyakarta: Puskadiabuma dan The Asia Foundation, 2008), hal. 91. 
dan menampilkan adanya fenomena gender dalam suatu masyarakat serta berbagai persoalan sosial-budaya yang ditimbulkannya. Dengan menggunakan perspektif ini, kepekaan kita terhadap fenomena ketidakadilan gender akan menjadi lebih kuat. Kita dapat memberi perhatian pada pola-pola interaksi, relasi dan pemisahan sosial antara laki-laki dan perempuan, serta berbagai macam implikasinya. ${ }^{19}$

Pengembangan civic values melalui pemberdayaan ekonomi masyarakat bersama pesantren dilakukan dengan paradigma bottom-up. Alur pemberdayaan ini adalah sebagai berikut secara berurutan: kegiatan Preliminary Workshop, need assessment, Workshop Penyusunan dan Penulisan Modul Pemberdayaan Masyarakat Bersama Pesantren Berbasis Pengembangan Civic Values, Training of Trainers (TOT) Participatory Rural Appraisal(PRA), Pembentukan Kelompok Masyarakat (Pokmas), In-Service Training (IST) Participatory Rural Appraisal (PRA), halaqah bulanan Pokmas, dan In-Service Training (IST) Applied Technology. ${ }^{20}$

Penghubungan nilai-nilai pluralisme, demokrasi, dan gender dengan pemberdayaan ekonomi masyarakat yang digerakkan pesantren memiliki tiga signifikansi, yaitu, pertama, pengangkatan ketiga nilai tersebut yang berkembang secara umum mendorong terjadinya komunikasi dengan kajian keislaman pesantren mengenai ketiga nilai tersebut, kedua, ketiga nilai tersebut dipahami sebagai modal sosial ekonomi, dan ketiga, karena pentingnya ketiganya sebagai modal sosial ekonomi, dalam proses pemberdayaan ekonomi sekaligus muncul pentingnya kesadaran mengenai ketiga nilai tersebut sehingga lahir mentalitas yang inklusif, yang mendorong partisipasi setiap orang, dan yang mengambangkan kemitraan dan kerjasama antara perempuan dan laki-laki.

Oleh karena itu, ada beberapa keuntungan dalam kegiatan pengembangan civic values melalui pemberdayaan ekonomi masyarakat bersama pesantren. Keuntungan pertama adalah terjadinya pemberdayaan ketrampilan berkegiatan ekonomi masyarakat bersama pesantren, yang berpotensi memberikan lapangan pekerjaan anggota masyarakat sekitar pesantren dan komunitas pesantren itu sendiri, sehingga menyumbang upaya pengentasan kemiskinan. Keuntungan kedua, komunitas pesantren menjadi lebih dekat dengan masyarakatnya. Keduanya bersatu-

19 Heddy Shri Ahimsa-Putra, "Gender dan Pemaknaannya: Sebuah Ulasan Singkat”, Makalah Disampaikan dalam Workshop "Sensivitas Gender dalam Manajemen”, PSW IAIN Sunan Kalijaga, 28 September 2000, hal. 7-8.

${ }^{20}$ Hasil wawancara dengan direktur Puskadiabuma Pascasarjana UIN Sunan Kalijaga, Muqowim, M.Ag. pada tanggal 3 Agustus 2010. 
padu, tidak hanya dalam memajukan pengetahuan keagamaan Islam, tetapi juga pengembangan ekonomi masyarakat. Keuntungan ketiga, terjadi pemahaman nilainilai pluralisme, demokrasi, dan gender yang interkonektif-integratif dengan pemahaman tradisi keislaman pesantren. Interkoneksi-integrasi pemahaman ketiganya dipandang lebih mudah diterima atau sedikit resistensi karena memberi kontribusi konkret pada ketrampilan pengembangan ekonomi masyarakat pesantren dan hasilnya kembali kepada kebaikan dan perbaikan ekonomi masyarakat dan pesantren penggeraknya. Keuntungan keempat adalah terdiseminasikannya nilainilai pluralisme, demokrasi, dan gender dalam masyarakat dan pesantrennya. Mulanya mereka memandang penting ketiganya dalam kegiatan berekonomi, tetapi dimungkinkan muncul kesadaran pentingnya ketiganya dalam bidang lainnya seperti beragama, bermasyarakat, berpolitik. Keuntungan terakhir, kegiatan seperti ini bisa dijadikan refleksi untuk meninjau dan memberika saran bagi pengembangan kebijakan penentasan kemiskinan selama ini di Indonesia.

\section{Keadaan Pesantren Sebelum dan Sesudah Pemberdayaan}

Sebelum diberdayakan kedua pesantren belum mengerti apa yang dimaksudkan pemberdayaan ekonomi yang digerakkan pesantren dengan basis pengembangan civic values. Di kedua pesantren belum ada usaha ekonomi bersama antara masyarakat dan pesantren. Kedua pesantren awalnya pesimis dengan rencana pemberdayaan yang ditawarkan. ${ }^{21}$

Setelah mengalami pemberdayaan bersama Puskadiabuma, terjadi perubahan yang cukup signifikan. Aktivitas kegiatan berekonomi bersama masyarakat menjadi fenomena baru yang banyak memberi inspirasi bagi masyarakat sekitarnya, mereka mulai bisa merasakan hasil pemberdayaan secara konkret yang berpengaruh pada perbaikan ekonomi. Mereka juga semakin menyadari pentingnya nilai-nilai pluralisme, demokrasi, dan gender dalam menjalankan kegiatan berekonomi. Keadaan setelah pemberdayaan lainnya yang bisa disebutkan adalah kesan baru kedua pesantren terhadap kegiatan pemberdayaan seperti ini.

\section{Pesantren Tarbiyatun Nasyi'in Pacul Gowang Jombang}

Pesantren Tarbiyatunnasyiin Pacul Gowang berdiri, dilihat dari segi nama Tarbiyatunnasyiin, tahun 1930. Nama Tarbiyatunnasyiin diberikan oleh pengasuh

21 Wawancara dengan Muqowim, M.Ag, Direktur Puskadiabuma dan Ir. Senthot Burhanuddin Ihsan, Fasilitator Pusat kegiatan pemberdayaan pada 30 Agustus 2010. 
yang ketiga, yaitu KH. Manshur Anwar. Sebelumnya di bawah pengasuh pertama dan kedua, yaitu KH. Alwi Daud yang mendirikan dan mengasuh pertamakali pesantren ini sejak tahu 1885, dan KH. Anwar Alwi yang mengasuh mulai tahun1911, pesantren ini masih bernama Pondok Pesantren Pacul Gowang. ${ }^{22}$ Sepeninggal KH. Manshur Anwar, pesantren ini diasuh oleh pengasuh keempat, yaitu KH. Muhammad Abdul Aziz Manshur sejak tahun 1983. Atas inisiatif beliau, Yayasan Ma'had Tarbiyatunnasyiin didirikan untuk menaungi segala kegiatan pesantren Tarbiyatunnasyiin dengan Nomor Badan Hukum Akte Notaris C-772.HT.03.01Th. 2004 dan Tanggal Badan Hukum 11 Desember 2007. Ketua yayasan ini adalah KH. Muhammad Abdul Aziz Manshur sendiri yang dibantu oleh HM. Shobih AlMu'ayyad selaku wakil ketua, Moh. Alwi Abdillah selaku sekretaris, dan H. Abdul Mu’id Shohib selaku bendahara. Adapun alamat pesantren adalah Jl. KH. Manshur Dsn. Paculgowang Ds. Diwek Kab. Jombang Jawa Timur, Alamat Pos: Tromol Pos 03 Cukir Diwek Jombang 61471.23

Masyarakat desa Jatirejo memiliki komoditas pertanian paling besar adalah padi, disusul jagung dan kacang tanah. Sedangkan dalam bidang perkebunan, lahanlahan milik masyarakat ditanami salak dan durian. Dalam bidang peternakan, ayam pedaging/broiler menduduki rangking paling tinggi, menyusul berikutnya burung puyuh dan ayam kampung. Desa Jatirejo masyarakatnya di samping petani juga banyak yang memiliki usaha anyaman bambu. Para pengrajin bambu di desa ini tidak menjual hasil kerajinan mereka ke luar daerah, sudah ada pengepul di desa yang membeli hasil anyaman. Sedangkan dusun Paculgowang dikenal dengan sentra produksi tahu. Hasil produksi tahu Paculgowang terkenal di kabupaten Jombang bahkan sampai kabupaten Kediri.

Setelah mengikuti program pemberdayaan, Pokmas Pesantren Tarbiyatun Nasyi'in Jombang mengembangkan tiga jenis kegiatan ekonomi, yaitu bidang pertanian, peternakanm dan home industry. Pertanian yang dikembangkan oleh Pokmas Pesantren Tarbiyatun Nasyi'in adalah jenis pertanian organik. Pilihan ini dibuat oleh Pokmas karena mayoritas pertanian yang dilakukan masyarakat sekitar pesantren adalah pertanian yang lebih dominan mengandalkan pupuk kimia.

Meskipun awalnya ragu dengan pertanian organik, akhirnya mereka menjadi yakin setelah dipraktekkan melalui lahan percontohan, yang diberikan oleh pengasuh

${ }^{22}$ Tim Penyusun, Profile Pondok Pesantren Tarbiyatun Nasyi'in Paculgowang Jombang (Jombang: Pondok Pesantren Tarbiyatun Nasyi'in, 2009).

23 Ibid. 
pesantren. Lahan sawah percontohan itu sebelumnya memang telah dipakai untuk bertani tanaman padi, tetapi masih menggunakan pemupukan secara kimiawi. Luas lahan tersebut sekitar $2.000 \mathrm{~m} 2$. Awalnya, tanah sawah itu hanya bisa menghasilkan padi kurang dari $1000 \mathrm{~kg}$, namun setelah panen pertama pertanian organik, padi yang dihasilkan sekitar $1200 \mathrm{~kg}$, dan pada panen berikutnya rata-rata $1400 \mathrm{~kg}$. Masyarakat yang diundang untuk menyaksikan perbandingan hasil antara penanaman padi secara organik dan kimiawi, sedikit demi sedikit mulai menaruh minat. Hal ini terbukti, beberapa kali fasilitator pesantren dan anggota Pokmas praktisi pertanian organik diundang oleh warga masyarakat dan diminta memberikan pelatihan bertani secara organik..$^{24}$

Sebenarnya di daerah Tawangsari Pacul Gowang Jombang, terutama di daerah pinggiran terdapat banyak peternak ayam baik potong maupun petelur. Keberadaan peternak ayam ini sebelum adanya Pokmas ini sering menjadi sumber konflik antara pemilik ternak dan masyarakat sekitar. Di samping bau kotoran ternak yang dipandang sangat mengganggu warga, yang lebih mengganggu adalah banyaknya lalat yang ditimbulkan oleh peternakan ke rumah-rumah warga. Bahkan pada tahun 2007 dulu pernah ada tuntutan warga agar peternakan ayam di pindahkan, tetapi bagi peternak tidaklah mungkin dilakukan karena beternak ayam adalah satu-satunya mata pencaharian mereka. Berbagai musyawarah untuk mengatasi persoalan tersebut mengalami jalan buntu.

Kemudian "rembugan" para anggota Pokmas dalam halaqah memutuskan untuk mengundang para peternak untuk rencana pengambilan dan pemanfaatan kotoran ternak ayam mereka. Para peternah menyambut baik rencana tersebut. Kotoran ternak mereka dibiarkan untuk diambil Pokmas, bahkan sebagian justru mau memberi upah yang mau mengambil kotoran ternaknya. Kemudian kotoran itu dibuat pupuk organik bersama sampah-sampah organik yang melimpah di daerah tersebut. Setelah direalisasi pengambilan dan pemanfaatan kotoran ternak ayam menjadi pupuk oraganik, masalah bau dan lalat di daerah itu pelan-pelan hilang. Para peternak ayam yang awalnya mau mengupah siapa saja yang mau mengambil kotoran ternaknya, kemudian mereka tidak mau memberi upah, bahkan sebagian dari peternak ikut membuat pupuk organik untuk keperluan mereka sendiri. Bahkan sekarang ini, anggota Pokmas harus membeli untuk mendapatkan kotoran ternak ayam tersebut. ${ }^{25}$

24 Wawancara dengan Ir. Senthot Burhanuddin Ihsan, Ir. Nucky Menurwati, dan Drs. Ngadimin Chalimi, Fasilitator Pusat kegiatan pemberdayaan pada 1 September 2010.

25 Ibid. 
Anggota Pokmas menyebut lahan percontohan pertanian organik mereka dengan nama TOP (Pertanian Organik Pacul Gowang). Sewaktu magang, masingmasing pesantren, termasuk Pesantren Tarbiyatun Nasyi' in, diberi dana stimulus oleh Puskadiabuma sebesar Rp. 10.000.000,-. Biasanya dalam pelatihan-pelatihan dengan pendekatan wacana, peserta hanya berpikir mencari uang, tetapi pelatihan ini memberi pengalaman yang positif, karena menyadari manfaat pelatihan yang mereka dapat dengan pendekatan kebutuhan yang bisa mengatasi problem ekonomi, mereka tidak membagi habis uang stimulus tersebut, melainkan justru dijadikan modal awal berkoperasi anggota Pokmas, mereka bisa melakukan simpan pinjam, untuk sebagian dan sebagian digunakan untuk realisasi kegiatan.

Setelah berusaha menerapkan pertanian organik, di samping warga masyarakat sekitar, banyak pihak yang menyambut positif kegiatan Pokmas yang digerakkan pesantren ini. Hal ini terbukti, salah satunya, dengan adanya perhatian PPL kecamatan yang mau mendampingi para petani setelah adanya pembentukan Pokmas dan selama kegiatan IST Applied Technology. Sebelumnya, belum pernah ada PPL yang mendampingi para petani di desa ini. Selain itu, aparat desa, terutama kepala desa sangat mendukung kegiatan yang berangkat dari inisiatif warga ini.

Jenis kedua pilihan Pokmas yang dikembangkan adalah peternakan, terutama kambing. Perwakilan anggota Pokmas dikirimkan ke Sleman, Yogyakarta, untuk magang cara beternak kambing yang benar. Selama enam hari mereka diberi pengetahuan dan keterampilan tentang tata cara memilih kambing (peranakan ettawa/PE), cara membuat makanan, cara memberi makan, cara mengolah kotoran menjadi pupuk cair dan padat, memerah susu, mengeringkan dan mengemas susu cair menjadi susu bubuk. Melalui kegiatan ini, mereka lebih mengerti tentang permasalahan beternak kambing dan cara mengatasi permasalahan yang muncul.

Setelah selesai magang, peserta mensosialisasikan hasil melalui halaqah Pokmas. Melalui media ini, kemudian disepakati membuat kandang kambing yang akan dikelola oleh Pokmas. Setelah kandang ada, mereka mengkoordinasi para anggota Pokmas yang mempunyai kambing untuk dijadikan satu kandang dan dipelihara bersama. Dalam jangka panjang, semua yang berasal dari kambing dapat dimanfaatkan bersama, baik susu maupun limbah kotoran ternaknya. Banyak di antara anggota Pokmas yang kemudian membeli kambing dan ditempatkan di kandang milik Pokmas. Saat ini, ada sekitar 20 kambing PE dan 35 kambing gibas yang dikelola Pokmas. Bahkan, beberapa waktu yang lalu di antara kambing tersebut diikutkan dalam kejuaraan kambing PE, dan ternyata menjadi juara. 
Di samping ternak kambing PE, Pokmas juga membuat usaha ternak ayam, meskipun belum berskala besar, tetapi ini untuk mengamankan stok pengiriman ayam ke Warung Ayam Bakar Wong Solo yang ada di Mojokerto dan cabangnya di Jombang. Setiap hari warung tersebut siap menerima 50 ekor ayam untuk dijual. Sejak keberhasilan menyelesaikan masalah kotoran ternak ayam yang ditimbulkan para peternak ayam, Pokmas semakin dipercaya oleh mereka dan masyarakat sekitarnya. Atas inisiatiif Pokmas, para peternak ayam di sekitar daerahnya dengan senang hati dikoordinasi oleh Pokmas untuk memenuhi permintaan pasokan ayam untuk warung tersebut. Hal ini menunjukkan bahwa Pokmas telah menjadi media komunikasi yang baik antara pesantren dan masyarakat dan memberi keuntungan ekonomi untuk masyarakat sekitar, di samping memberi keuntungan bagi para anggota Pokmas. ${ }^{26}$

Menurut pengasuh pesantren yang telah lama berdiri sejak sebelum kemerdekaan ini, KH. Abd. Aziz Manshur menilai bahwa pelatihan yang dilakukan oleh Puskadiabuma ini sangat positif, dan untuk pesantren dewasa ini model pemberdayaan yang seperti ini perlu terus dikembangkan. Lebih lanjut beliau mengatakan sedih, ketika mendengar bahwa kegiatan ini hanya akan berlangsung tiga tahun, dan berharap akan ada lembaga-lembaga lain seperti Puskadiabuma dalam mengembangkan peran pesantren yang secara nyata dirasakan manfaatnya, di luar rutinaitas kegiatan yang murni keagamaan, oleh masyarakat sekitar pesantren. Kegiatan seperti ini juga semakin mendekatkan dan mengakrabkan pesantren dengan masyarakat dan masyarakat dengan pesantrennya. ${ }^{27}$

Sementara Gus H. Adib Hamzawi melihat model pemberdayaan yang dikembangkan ini menarik, karena peserta tidak diberi kegiatan ekonomi, melainkan difasilitasi untuk menemukan kegiatan ekonomi yang cocok dengan potensi daerahnya. Ini merupakan pendekatan yang benar-benar demokratis dan menciptakan keberdayaan peserta kegiatan. Yang lebih menarik model pemberdayaan ini didasarkan pada basis nilai yang kalau dalam wacana muncul banyak masalah, tetapi dalam praktek sederhana berdemokrasi dalam bentuk mendorong partisipasi setiap warga anggota Pokmas, memahami perbedaan untuk optimalisai hasil usaha ekonomi, dan memberi peran perempuan yang lebih dalam kegiatan membuat

${ }^{26}$ Hasil wawancara dengan ustadz Muh. Lukman Hakim, fasilitator Pesantren Tarbiyatun Nasyi' in pada tanggal 19 September 2010.

27 Hasil wawancara dengan KH. Abd. Aziz Manshur, pengasuh dan sekaligus ketua Yayasan Pesantren Tarbiyatun Nasyi' in pada tanggal 18 September 2010. 
kami dan masyarakat anggota pokmas bisa mengerti nilai-nilai tersebut penting bukan dari penerimaan melalui definisi-definisi istilah-istilah tersebut, melainkan melalui praktek dalam dinamika kegiatan Pokmas, dan ini sama sekali tidak bertentangan dengan nilai-nilai moral Islami. ${ }^{28}$

Ustadz Muh. Lukman Hakim merasa bersyukur sekali dilibatkan sebagai fasilitator pesantren. Pertama, dia mengaku mendapat ilmu dan ketrampilan yang sangat berharga, yang dulunya tidak ada bayangan sedikit pun. Yang lebih menyenangkan ternyata kegiatan usaha ekonomi bersama ini, juga bisa mengatasi konflik sosial di desanya, bahkan pihak-pihak yang berkonflik justru bisa bekerjasama di bawah koordinasi Pokmas untuk usaha ekonomi produktif. ${ }^{29}$

\section{Pesantren Al-Hikmah Sumberejo Gunung Kidul}

Pondok Pesantren Al Hikmah berdiri pada tahun 1989 setelah Yayasan AlHikmah Sumberjo selaku institusi penyelenggara Pondok Pesantren Al-Hikmah Sumberjo, Karangmojo, Gunungkidul, Daerah Istimewa Yogyakarta, resmi berdiri sejak tahun 1989. Tepatnya sejak lahirnya Akte Notaris Daliso Rudianto,SH No.21 tertanggal 10 Juli 1989 dan tercatat pada Panitera Pengadilan Negeri Wonosari tgl.7 Agustus 1989 No.1/Apesach/ Y / VIII / 1989. ${ }^{30}$

Pesantren al-Hikmah dilihat dari segi kelahirannya, boleh dibilang termasuk pesantren yang relatif masih muda. Pada saat ini pesantren Al-Hikmah Sumberjo diasuh oleh: K. H. Harun Al Rosyid (Pimpinan Pesantren Al Hikmah), Ustd. Hanung Hisbullah Hamda, SH (Pimpinan Pesantren Bidang Kurikulum Akademik/Pengajaran), serta Ustd. Riyanto Abu Azzam (Pimpinan Pesantren Bidang Pengasuhan Santri). ${ }^{31}$

Dari tahun ke tahun santri Al Hikmah jumlahnya semakin meningkat pesat. Sebagai ilustrasi, pada tahun 2000 jumlah santrinya baru sekitar 120 orang sekarang (2010) jumlah santri telah mencapai angka 600 orang lebih yang semuanya belajar secara tersebar di MA Al Hikmah, SMK Al Hikmah, SMP Al Hikmah, dan di Panti Asuhan Yatim Piatu Al Hikmah. ${ }^{32}$

${ }^{28}$ Hasil wawancara dengan Gus H. Adib Hamzawi, putra pengasuh Pesantren Tarbiyatun Nasyi' in pada tanggal 19 September 2010.

29 Hasil wawancara dengan ustadz Muh. Lukman Hakim, fasilitator Pesantren Tarbiyatun Nasyi' in pada tanggal 19 September 2010.

30 Tim Penyusun, Profil Kelembagaan dan Kegaitan Pondok Pesantren Al-Hikmah Sumberejo Karangmojo Gunung Kidul (Gunung Kidul: Pondok Pesantren Al-Hikmah, 2007).

31 Ibid.

32 Ibid. 
Gunung Kidul dikenal dengan peternakan kambing yang cukup potensial. Di desa-desa di daerah ini dikenal hampir di setiap rumah petani terdapat usaha ternak kambing baik dalam skala kecil-kecilan sampai ada yang memiliki kambing yang cukup banyak. Masyarakat sekitar Pesantren Al-Hikmah sendiri tidak sedikit yang menggantungkan ekonomi keluarganya pada ternak kambing, dan sebagian kecil ternak sapi.

Di daerah sekitar lokasi Pesantren Al-Hikmah terdapat banyak tanaman jambu mete. Di desa Sumberejo dan sekitarnya di Gunung Kidul, hampir setiap rumah memiliki pohon jambu mete. Usaha makanan kecil yang berbahan biji mete dari buah jambu mete telah menjadi pekerjaan rumah tangga masyarakat di daerah ini. Namun, sayangnya, pemanfaatan nilai ekonomi dari jambu mete hanya berhenti di penggunanaan biji metenya saja, sementara buah jambu metenya, yang tidak termakan, terbuang percuma sebagai limbah yang sia-sia.

Jenis pertama pilihan Pokmas Pesantren Al-Hikmah Sumberejo Gunung Kidul yang dikembangkan adalah peternakan, terutama kambing. Setelah selesai magang, peserta mensosialisasikan hasil melalui halaqah Pokmas. Melalui media ini, kemudian disepakati membuat kandang kambing yang akan dikelola oleh Pokmas. Sepulang dari magang dan setelah musyawarah antara pesantren dan masyarakat dalam Pokmas, Pokmas langsung membuat kandang secara swadaya dari 10 orang, di lokasi pekarangan salah satu peserta. Kandang diisi dengan kambing milik peserta dan ditambah dengan pembelian hasil iuran 10 orang. Sejak tahun 2009, kelompok peternak yang juga anggota Pokmas ini telah bisa mengambil untung berupa susu kambing. Mereka memerah susu tersebut dan mengolah susu segar menjadi susu bubuk dan dijual di sekitar desa mereka.

Pilihan usaha ekonomi kedua, Pokmas Pesantren Al-Hikmah Gunung Kidul memilih budidaya jambu mete sebagai salah satu usaha ekonomi yang ingin dikembangkan. Setelah dari magang di pengolahan jambu mete di rumah di Gunung Kidul juga, namun cukup jauh dari lokasi pesantren, dengan didampingi oleh narasumber pelatihan yang bukan muslim, melainkan seorang nasrani, mereka menyadari nilai ekonomi yang lebih besar dari buah jambu mete. Ternyata, selain metenya, buahnya bisa dibuat kreasi makanan dan minuman yang beragam dan bernilai rupiah lumayan tinggi. Darinya bisa dibuat sirup jambe mete atau jus jambu mete yang dikemas dalam botol atau kelas atau kaleng. Selain itu, buah jambu mete juga bisa dibuat sebagai campuran pembuatan abon baik dari daging sapi maupun ayam. Bahkan, jika mau melakukan fermentasi terhadap buah jambu 
mete bisa diproses menjadi minuman arak buah jambu mete, dan pasarnya sudah jelas dan siap menerima, yaitu di Bali.

Sepulang dari magang, mereka bersepakat membuat sirup dan jus buah jambu mete serta membuat abon sapi dengan campuran serat buat jambu mete. Sejak ada kegiatan Pokmas membuat sirup dan jus serta campuran abon sapi dengan bahan dasar daging atau buah jambu mete, ternyata mendapat respon yang cukup baik oleh pasar lokal. Warga sekitar, di luar Pokmas, setelah tahu hasil dan optimalisasi nilai ekonomi dari jambu mete, sudah banyak yang mulai mengikuti membuat produk-produk berbahan dasar dari daging jambu mete tersebut.

Pilihan Pokmas yang ketiga adalah pembuatan instalasi biogas. Setelah pulang magang, dan melihat instalasi biogas yang sudah nyala, Pokmas pesantren ini tertarik untuk membuat instalasi biogas di pesantrennya dengan bahan dasar gas urin, feces santri, dan kotoran ternak yang dimiliki pesantren dan bisa didapat di peternakan sekitar daerah itu.

Selama ini, menurut Pengasuh Pesantren Al-Hikmah, K.H. Harun Al-Rasyid, mengatakan bahwa setiap bulan pesantren menghabiskan kayu bakar tidak kurang sebanyak dua truk untuk memasak dengan harga Rp. 1.700.000 demi kebutuhan memberi makan para santrinya. Selain itu, pesantren juga memerlukan kebutuhan air bersih yang tiap bulannya tidak kurang habis biaya sebesar Rp. 1.000.000. Sementara mencari kayu bakar berisiko mempercepat rusaknya pepohonan di daerah setempat. Terdorong dengan keadaan dan kebutuhan pesantren untuk penghematan biaya kesehariannya dalam memenuhi kebutuhan pangan santri, Pokmas dalam diskusi-diskusinya di beberapa halaqah memutuskan untuk membuat instalasi biogas dengan dana stimulasi Rp. 10.000.000,- dari Puskadiabuma ditambah dengan iuran para pengasuh pesantren dan iuran warga masyarakat. Halangan fiqih mengenai penggunaan feces manusia untuk keperluan bahan gas dalam biogas, para anggota Pokmas mengkonsultasikannya dengan para pengasuh pesantren, dan dalam pandangan para pengasuh pesantren, penggunaan feces manusia untuk bahan biogas tidak menjadi masalah, mereka memandang secara fiqih dibolehkan. ${ }^{33}$

Kemudian, dibuatlah instalasi biogas tersebut yang bahan dasar gasnya salah satunya adalah limbah para santri yang berjumlah sekitar 700 orang, baik yang berupa feces maupun urin. "Dengan selesainya instalasi biogas maka banyak pohon dapat terselamatkan karena tidak perlu lagi menebang pohon hanya untuk memasak

33 Wawancara dengan K.H. Harun Al-Rosyid, Pengasuh Pesantren AL-Hikmah pada tanggal 25 September 2010 
air maupun makanan para santri," katanya. Ia mengatakan, untuk memenuhi kebutuhan memasak dan biaya hidup bagi sebanyak 700 santri memang diperlukan dana yang tidak kecil, padahal pesantren ini menggratiskan biaya pendidikan mereka. "Pendidikan gratis bagi santri yang menimba ilmu di pesantren Al-Hikmah sebagai upaya memberikan rasa keadilan bagi keluarga miskin," katanya. Menurut dia, santri yang dididik di pesantrennya adalah mereka yang berasal dari keluarga miskin dan terpinggirkan, sehingga para santri tidak dipungut biaya alias gratis. ${ }^{34}$

Menurut K.H. Harun Al-Rasyid, pengasuh Pesantren Al-Hikmah, pemberdayaan yang dilakukan Puskadiabuma sangat berharga dan kontribusinya konkret. Bagi pesantren sendiri, salah satu yang dirasakan adalah meringankan beban pembiayaan dalam menghidupi santri dengan gagasan biogas tersebut. Selain itu, model pemberdayaan ini penting dikembangkan di masyarakat miskin manapun, meskipun kegiatan ekonomi yang berskala kecil tetapi itu sangat memberi sumbangan bagi penopangan hidup seharihari mereka dari kemauan mereka sendiri. Gus Hanung menambahkan bahwa kegiatan pemberdayaan Puskadiabuma ini saya pandang bisa menjadi model untuk pendampingan usaha-usaha mikro di wilayah pedesaan dan sekaligus bisa menjadi jawaban untuk mengatasi kemiskinan dari desa dengan menumbuhkan motivasi berkegiatan ekonomi dari inisiatif masyarakat bawah. Nilai-nilai civic values harus menjadi inti pengembangan ekonomi. Usaha ekonomi tanpa basis nilai bisa buta pada kepedulian sosial. ${ }^{35}$

Sementera para fasilitator pesantren, hampir berpandangan mirip mengenai kesan pemberdayaan yang mereka alami. Menurut mereka, kekuatan alur kegiatan yang didesain Puskadiabuma ada pada paradigmanya yang mendorong pemecahan dari subjek yang diberdayakan, tidak didikte, dan yang paling penting bimbingan dan pendampingan yang intensif menjadi kunci keberhasilan tersendiri. Mereka menjadi sadar bahwa dalam usaha pengentasan kemiskinan di masyarakat yang terpenting adalah perubahan mindset atau pola pikir melalui pendampingan dan penyadaran. Porsi ini harus lebih besar diberikan ketimbang memberikan "kue" ekonomi, yang terakhir ini justru tidak begitu penting. Perubahan pola pikir dan penciptaan motivasi terus-menerus adalah kunci. Pola pikir di sini termasuk sikap terhadap nilai-nilai civic values. ${ }^{36}$

34 Seperti dituturkan oleh Ustadz Hanung dalam wawancara denganya tanggal 25 September 2010, meskipun menurut dia itu masih rencana, saat ini belum terealisasi, tetapi beberapa kali pembicaraan dan survey telah dilakukan.

35 Wawancara dengan K.H. Harun Al-Rasyid dan Ustadz Hanung pada tanggal 25 September 2010

${ }^{36}$ Hasil wawancara dengan ustadz Widodo, ustadz Riyanto, dan ustadzah Sudarsiti, fasilitatorfasilitator Pesantren Al-Hikmah Gunung Kidul pada tanggal 25 September 2010. 


\section{Lesson Learn dari Hasil Pemberdayaan}

Dari aktivitas pemberdayaan ekonomi masyarakat bersama pesantren berbasis civic values sebagaimana telah dilihat hasilnya dari dua pesantren di atas, peneliti mendapat gambaran bahwa civic values kelihatan dalam beberapa kegiatan Pokmas. Beberapa praktek nilai-nilai penghargaan atas kemajemukan atau pluralisme, demokrasi, dan gender secara sederhana bisa dilihat, di antaranya:

1. Adanya partisipasi masyarakat, yang ada di Pokmas, untuk berdaya melalui kegiatan ekonomi bersama-sama dengan pesantren. Munculnya partisipasi masyarakat bawah untuk menggerakkan sektor ekonomi ini penting dicermati mengingat banyak kebijakan di bidang ekonomi, terutama pertanian dan peternakan yang tidak memihak pada kepentingan masyarakat. Paradigma yang dibangun bukan memberdayakan masyarakat dengan memberikan bekal pengetahuan dan ketrampilan, namun lebih pada "memberikan ikan, bukan kailnya".

2. Adanya partisipasi aktif kaum perempuan anggota Pokmas dalam menggerakkan kegiatan ekonomi merupakan bentuk pemberdayaan kaum perempuan. Melalui ekonomi, kaum perempuan lebih mempunyai peran lebih produktif. Mereka akhirnya menyadari bahwa jika diberdayakan dengan benar, potensi mereka sangat banyak. Mereka juga mampu menunjukkan peran untuk meningkatkan kesejahteraan bersama. Melalui Pokmas, kepala desa, terutama di desa Pesantren Tarbiyatun Nasyi'in, yang juga perempuan sangat mendukung kegiatan Pokmas.

3. Munculnya kesadaran warga masyarakat anggota Pokmas tentang hak-hak ekonomi yang selama ini kurang disadari dan diberdayakan. Kesadaran ini memunculkan kesadaran akan hak-hak selaku warga yang sejauh ini hanya menjadi objek pembangunan, bukan sebagai subjek pembangunan.

4. Munculnya kesadaran bahwa dalam pemberdayaan ekonomi, masyarakat pesantren dapat menjalin kerjasama dengan siapa saja, tanpa mempertimbangkan latar belakang seseorang, seperti etnis ataupun agama. Menurut penuturan pengasuh Pesantren al-Hikmah Gunung Kidul, pihak pesantren sampai sekarang masih tetap menjalin hubungan baik dengan pelatih ketrampilan memberdayakan jambu mete secara optimal yang adalah orang kristiani. Pesantren ini dulunya amat menghindari mendengarkan sesuatu dari 
narasumber non muslim, tetapi sejak pengalaman dalam pemberdayaan ekonomi ini, mereka mengubah pandangan sempit ini. ${ }^{37}$

5. Tingkat resistensi memasukkan isu-isu keadaban dan kewargaan (pluralisme, demokrasi, HAM dan gender) melalui pengembangan ekonomi masyarakat berbasis pesantren lebih rendah, ketimbang langsung bermaksud mendialogkan Islam dan isu-isu keadaban dimaksud. Tampaknya, yang pertama lebih rendah resistensinya, karena masuk melalui mu'amalah, yang kedua lebih tinggi karena masuk melalui aqidah, faith.

6. Dari berjalannya program ini, beberapa pesantren menyadari bahwa tanggung jawab sosial institusi pesantren sama besar maknanya dengan tanggung jawab pendidikan keagamaan. Dengan melakukan hal kecil bersama masyarakat berupa kegiatan berekonomi tertentu, mereka menemukan makna yang meluas tentang agama; agama tidak hanya mengajarkan ajaran-ajaran dan ritual religius, tetapi juga menghidupkan nilai-nilai kebaikan yang ada di masyarakatnya.

\section{E. Kontribusi terhadap Kebijakan Pengentasan Kemiskinan di Indonesia}

Pemerintah telah berupaya keras dengan berbagai program untuk mengadakan pemberdayaan masyarakat miskin, misalnya melalui program IDT, P2KP, Askeskin, kompensasi BBM, PPK, dan lain sebagainya. Tetapi sayangnya program-program ini juga hanya berkutat pada paradigma memberi untuk mengatasi kekurangan dari pihak kaum miskin. Program-program tersebut belum cukup kuat dalam membuat kaum miskin berdaya untuk mengembangkan diri dan madiri secara ekonomi. Program-program tersebut justru menciptakan ketergantuangan yang luar biasa, sehingga secara jangka panjang membentuk suatu mentalitas menunggu pemberian, ketimbang mentalitas untuk bangkit dan berdikari.

Hal itu terjadi, karena preferensi kebijakan pemerintah penanggulangan kemiskinan di Indonesia masih berupa kebijakan ekonomi yang pro kapitalisme.

37 Wawancara dengan Ustadz K. Riyanto tanggal 25 Agustus 2010. Menurutnya, mengomentari pengalaman bekerjasama dengan Puskadiabuma, "LSM-LSM, juga pemerintah daerah ataupun pusat mestinya harus memperbanyak kegiatan pemberdayan sejenis ini, di mana kekuatannya ada pada pendampingan yang kontinyu dan komunikatif dalam kurun waktu kurang lebih 2-3 tahun. Pengaruhnya pada penciptaan inisiatif masyarakat bawah untuk berani berusaha sangat nyata, selain perluasan wawasan dalam memahami Islam yang melihat setiap ciptaan memiliki nilai yang luas tidak hanya keindahan, atau kemanfaatan ekonomi, tetapi juga nilai spiritualitas lingkungan hidup." 
Hal ini tidak mengada-ada, karena indikasinya, modal ekonomi hanya berkutat pada pengusaha-pengusaha besar, bahkan sebagian besar dari mereka adalah pengusaha asing. Belajar dari hasil pemberdayaan ekonomi masyarakat di dua pesantren dalam penelitian ini, sudah saatnya kebijakan yang mengabaikan sektor ekonomi masyarakat menengah ke bawah diubah menjadi kebijakan yang bersifat kerakyatan. Alokasi anggaran yang besar untuk menggerakkan ekonomi menengah ke bawah terrutama yang di desa-desa merupakan strategi terbaik untuk konteks masyarakat indonesia, karena akan semakin mempercepat menciptakan budaya mentalitas wirausahawan. Tentu keberhasilan program ini harus melalui strategi pemberdayaan yang berparadigma bottom up yang diprogramkan oleh pemerintah dengan pendekatan "memberikan kail" dan bukan "memberikan ikan".

Sudah saatnya, pemerintah mendorong lebih serius pemberdayaan ekonomi masyarakat di daerah-daerah miskin dengan memanfaatkan penggerakan institusiintitusi sosial termasuk di dalam institusi-institusi keagamaan. Pengalaman pemberdayaan ekonomi masyarakat bersama pesantren berbasis pengembangan civic values oleh Puskadiabuma di dua pesantren di atas menunjukkan hasil yang cukup memberi harapan, di mana masyarakat bisa menjadi terdorong bergerak dari dalam dan berdikari secara ekonomi, bahkan memberi harapan yang lebih jauh yaitu, pertama, kegiatan ekonomi tersebut sekaligus bisa menjadi media mengatasi lingkungan hidup, dan kedua, menciptakan agen-agen perubahan pengembangan usaha ekonomi di tingkat desa-desa seperti para fasilitor pesantren yang kemudian di luar desain banyak diminta warga sekitar bahkan sebagian di luar di desanya yang meminta mereka untuk dilatih.

Preferensi pemerintah dalam mengembangkan ekonomi msayarakat yang terpisah dari institusi-institusi sosial termasuk institusi-institusi keagamaan harus segera diubah. Pengintegrasian pengembangan ekonomi dengan institusi-institusi non ekonomi terutama institusi sosial dan keagamaan perlu segera diambil sebagai kebijakan strategis pengembangan ekonomi masyarakat untuk pengentasan kemiskinan. Selama ini sebagian kebijakan pemerintah memang telah menunjukkan suatu kebijakan ekonomi rakyat, tetapi eksekusinya yang terpusat dan tidak terdelegasi ke bawah, kalaupun sampai ke pemerintah-pemerintah daerah, mereka sering berhenti karena susah mencari mitra kerja di lapangan. Akhirnya, mereka sering hanya meminta masyarakat berupa kelompok-kelompok tani atau usaha membuat proposal kegiatan, tetapi hasilnya sering nihil karena tidak sedikit ternyata ditemukan kelompok-kelompok fiktif. 
Dari hasil riset terhadap pemberdayaan ekonomi masyarakat di dua pesantren tersebut sulit untuk menciptakan suatu kelompok usaha ekonomi yang fiktif. Hal ini karena kelompok usaha ekonomi atau disebut Pokmas dibentuk dari proses komunikasi antara warga masyarakat dan pesantren sebagai lembaga penggeraknya. Kemudian mereka didorong untuk menemukan usaha ekonomi dari inisiatif mereka sendiri, pesantren dan para fasilitator yang dibentuknya yang sebelumnya telah dilatih secara aktif mendampingi untuk up grade pengetahuan dan ketrampilan terkait dengan usaha-usaha ekonomi mereka.

Dengan cara demikian, pemerintah dari pusat sampai daerah bisa menggandeng institusi-institusi sosial dan keagamaan yang jumlahnya sangat banyak untuk menjadi motor penggerak seperti halnya dua pesantren di atas di wilayahnya masing-masing. Di Indonesia banyak ditemukan organisasi-organisasi sosial dan organisasi-organisasi agama. Mereka bisa dimanfaatkan berfungsi seperti pesantren dalam pemberdayaan ekonomi masyarakat dalam penelitian ini. Pemerintah tinggal menghitung-hitung anggarannya dengan skala prioritas yang berangkat dari daerah yang dipandang paling tertinggal, menuju daerah-daerah yang dipandang lebih maju. Organisasi-organisasi sosial dan organisasiorganisasi agama diberdayakan sebagai para penggerak-penggerak ekonomi masyarakatnya masing, dari pemetaan potensi sampai usaha ekonomi strategis dan konkret yang bisa dikembangkan. Pendampingan yang sungguh-sungguh dan berkelanjutan sampai masyarakat sendiri menguasai pengetahuan dan ketrampilan berekonominya, sehiingga pada gilirannya, mereka justru bisa menjadi pemberdaya-pemberdaya baru di tingkat lokal.

Kontribusi terakhir yang bisa diberikan di sini adalah pengembangan ekonomi yang sekaligus mendiseminasikan civic values atau nilai-nilai kewargaan. Tiga nilai, yaitu pluralisme, demokrasi termasuk di dalamnya isu-isu hak-hak asasi manusia, dan gender, yang awalnya disisipkan dalam kegiatan berekonomi dengan target terbangunnya kesadaran pentingnya nilai-nilai tersebut sebagai modal sosial ekonomi, pada tahap berikutnya bisa menjadi proses penyadaran nilai-nilai kewargaan dalam konteks hidup bermasyarakat dan bernegara. Hal ini sangat mendasar nilai kontribusinya tidak hanya pada optimalisasi pengembangan ekonomi, tetapi juga pada pengondisian tata hidup pergaulan antara warga yang di Indonesia didiami oleh ragam masyarakat dengan ragam latarbelakang baik etnis, suku, bahasa, budaya, tradisi, dan agama.

\section{F. Penutup}

Dari penjelasan dan uraian di atas, bisa disimpulkan bahwa pengembangan dan diseminasi civic values melalui pemberdayaan ekonomi masyarakat 
bersama pesantren dilakukan dengan paradigma bottom-up, artinya melibatkan secara aktif pesantren sebagai ujung tombak perubahan. Pemberdayaan yang dilakukan terhadap dua pesantren, yaitu Pesantren Tarbiyatun Nasyi'in dan Pesantren Al-Hikmah, ditinjau dari teori pemberdayaan masyarakat, sebenarnya masuk dalam teori community development, tepatnya yang berparadigma community based and driven empowerment, di mana masyarakat menjadi objek pemberdayaan tetapi sekaligus juga subjek pemberdayaan. Pemberdayaan ini menggunakan pendekatan Participatory Rural Appraisal (PRA) untuk menemukan potensi dan usaha ekonomi dari dalam masyarakat bersama pesantren, di satu sisi, dan di sisi lain, untuk sekaligus mempraktekkan nilainilai pluralisme, demokrasi, dan gender di dalam proses kegiatan berekonomi tersebut, sehingga nilai-nilai tersebut bisa disadari signifikasinya tidak hanya sebagai modal sosial ekonomi, tetapi juga sebagai makna nilai-nilai tersebut sebagai penguatan civil society.

Hasil-hasil dari pemberdayaan adalah, pertama, kedua pesantren dan masyarakatnya bisa menerima arti pentingnya nilai-nilai demokrasi, pluralisme, dan kesetaraan laki-laki dan perempuan lebih mudah atau lebih rendah tingkat resistensinya melalui pendekatan aktivitas ekonomi real daripada melalui diskusi-diskusi mengenai nilai-nilai tersebut dilihat dari perspektif Islam; kedua, mereka memiliki kegiatankegiatan usaha ekonomi secara mandiri yang memberi mereka penghasilan tambahan; ketiga, pemberdayaan seperti ini bisa menjadi model untuk mengakselerasi penanganan problem-problem kemisikinan dan pengentasannya dengan mengaktifkan orang-orang miskin yang didorong oleh institusi-institusi sosial-keagamaan.

Dalam perspektif filosofis, menyangkut isu-isu persamaan dan kebebasan dalam konteks keadilan ekonomi-politik, terdapat dua aliran utama, yaitu pembangunan ekonomi masyarakat yang menekankan pada kebebasan dan pembangunan ekonomi masyarakat yang mengedepankan persamaan. Aliran yang pertama terkenal dengan aliran kiri, dan yang kedua dikenal dengan aliran kanan. Pembangunan ekonomi masyarakat beraliran kiri menghargai kebebasan berdasar etos kerja dan karenanya bebas memperoleh kekayaan tanpa batas. Konsekuensinya, aliran ini mendukung pembangunan ekonomi berparadigma kapitalisme pasar bebas. Aliran yang satunya mementingkan sisi persamaan, terutama persamaan kemakmuran. Dengan pemerataan kemakmuran yang dipentingkan, aliran kanan dari pembangunan ekonomi masyarakat ini berparadigama sosialisme. 
Dari pelajaran pemberdayaan atas dua pesantren di atas, secara filosofis bisa direfleksikan bahwa usaha mengubah pola pikir masyarakat bisa menjadi sia-sia apabila kita tidak memberi mereka kebutuhan dasar untuk bertahan hidup secara ekonomi. Mereka bisa menjadi masa bodoh terhadap apa yang orang dewasa ini inginkan mengenai kebebasan untuk semua, jika kita tidak memberikan persamaan kemakmuran untuk mereka. Persamaan kemakmuran membuat mereka mudah mengerti apa itu nilai saling menghargai yang menjadikan semua manusia bebas. Hasil pemberdayaan tampaknya mendukung aliran kanan dari pembangunan ekonomi masyarakat. Tetapi, lebih tepatnya, sebenarnya tidak mendukung, hanya ditemukan bahwa dengan paradigma aliran kanan ini, upaya-upaya mengubah pola pikir manusia lebih mudah diterima jika disertai dengan pemberdayaan ekonomi yang membuatnya bisa bertahan hidup.

Berdasar refleksi filosofis tersebut, tulisan ini merekomendasikan beberapa hal:

Pertama, hasil riset menunjukkan suatu dukungan untuk penguatan kebijakan ekonomi kerakyatan. Oleh karena itu, sesegera mungkin kebijakan pemerintah tentang ekonomi yang berparadigma pro-kapitalisme diubah menjadi berparadigma kerakyatan, yang berpihak pada kelas ekonomi menengah ke bawah dengan pemberdayaan yang intensif, sehingga pemerintah Indonesia akan semakin cepat bisa mengatasi problem kemiskinan.

Kedua, selama ini penanganan kemiskinan dilakukan dengan kebijakan pembangunan ekonomi yang terpisah dari pembangunan institusi-institusi sosial termasuk di dalamnya institusi-institusi agama. Ke depan untuk percepatan keberhasilan ekonomi kerakyatan, pembangunan ekonomi harus diintegrasikan melalui pembangunan institusi-institusi sosial termasuk di dalamnya institusiinstitusi agama dengan konsep pemberdayaan ekonomi berparadigma "pemberian kail", bukan "pemberian ikan".

Ketiga, pengembangan ekonomi yang sekaligus mendiseminasikan civic values atau nilai-nilai kewargaan, yaitu, pluralisme, demokrasi termasuk di dalamnya isuisu hak-hak asasi manusia, dan gender berkontribusi pada bahwa pembangunan ekonomi sebaiknya tidak hanya ditujukan mengejar nilai ekonomi dan nilai penanggulangan kemiskinan, tetapi juga mengejar terdiseminasikan dengan nilainilai kewargaan tersebut dalam praktek berkegiatan ekonomi. Kesadaran nilai yang dari kegiatan berekonomi bisa berkembang menjadi pengondisian kesadaran tentang nilai-nilai tersebut dengan skala yang lebih luas dalam kehidupan beragama, bermasyarakat dan bernegara. 


\section{DAFTAR PUSTAKA}

Abbas, Muchtar. 1987. "Pesantren and Community Development: an Insider's Perspective" dalam Manfred Oepen and Wolfgang Karcher (eds.), The Impact of Pesantren. Jakarta: Friedrich Nauman Siftung, P3M and Technical University Berlin.

Al-Umari, Akram Diya. 1995. Madinah Society at the Time of the Prophet, trans. Huda Khattab. USA: The International Institute of Islamic Thought.

Ali, A. Mukti. 1992."Ilmu Perbandingan Agama, Dialog, Dakwah, dan Misi" dalam Burhanuddin Daja dan Herman Leonard Beck (eds.). IImu Perbandingan Agama di Indonesia dan Belanda. Jakarta: INIS.

Arikunto, Suharsimi. 1992. Prosedur Penelitian Suatu Pendekatan Praktek. Jakarta: PT. Rieka Cipta.

Berger, Peter L. and Luckmann, Thomas. 1966. The Social Construction of Reality, a Treatise in The Sociology of Knowledge. New York: Double Day \& Company.

Berger, Peter L. 1969.The Secred Canopy: Elements of a Sociological Theory of Religion. New York: Anchors Books.

Burhanuddin, Jajat. 2007. Islamic Knowledge, Authority and PoliticalPower: The Ulama in Colonial Indonesia. Leiden: Ph.D Dissertation-Universiteit Leiden.

Burhanuddin, Jajat; Prasetyo, Hendro; dkk. 2009. Civic Values di Indonesia

Pengalaman Pemberdayaan Pesantren. Jakarta: PPIM UIN Syarif Hidayatullah Jakarta,.

Craig, Gary and Mayo, Marjorie eds.. 1995. A Reader in Participation and Development. London: Zed Books Ltd..

Fakih , Mansour. 1999. Analisis Gender dan Transformasi Sosial.Yogyakarta: Pustaka Pelajar.

Fakih, Mansur dan Mansur Fakih, 1987. "Community Development in Pesantren Issues and Problems" dalam Manfred Oepen and Wolfgang Karcher (eds.), The Impact of Pesantren. Jakarta: Friedrich Nauman Siftung, P3M and Technical University Berlin.

Hadi, Sutrisno. 2000. Metodologi Penelitian. Yogyakarta: Andi Offset. 
Haidari, Amin. 2006. Transformasi Pesantren: Pengembangan Aspek Pendidikan, Keagamaan, dan Sosial. Jakarta: LeKDIS dan Media Nusantara.

Ma'arif, Syafi'i. 1999. "Universalisme Nilai-nilai Politik Islam menuju Masyarakat Madani," Profetika Jurnal Studi Islam, vol. I, No. 2 Juli.

Machasin. 2005. Respon Pesantren terhadap Civic Values. Makalah dipresentasikan dalam Public Hearing Pengembangan Pesantren, Hotel Sahid Yogyakarta, 31 Mei - 1 Juni.

Moleong, Lexi J.. 2009.Metodologi Penelitian Kualitatif. Edisi Revisi. Bandung: Remaja Rosdakarya.

Murray, John Courtney. 1960. We Hold These Truth. New york: Sheed \& Ward.

Raharjo, Dawam (ed.). 1985.Pergulatan Dunia Pesantren: Membangun dari Bawah. Jakarta: P3M.

Roswantoro, Alim. 2005."Civic Values: Membangun Visi Warga dan Kewargaan Menuju Masyarakat Madani, Perspektif Filsafat Sosial” dalam Jurnal Pemikiran Filsafat dan Pemikiran Keislaman Refleksi, vol. 5 No. 2 Juli.

Roswantoro, Alim. dan Sodik, Mochamad. 2008. Nilai-nilai Masyarakat Madani dalam Pemberdayaan Ekonomi. Yogykarta: Puskadiabuma dan The Asia Foundation.

Ruhaini Dz., Siti. 2002. "Pengantar", dalam Islam dan Konstruksi Seksualitas. Yogyakarta: PSW IAIN- The Ford Foundation-Pustaka Pelajar.

Shri Ahimsa-Putra, Heddy. 2000. "Gender dan Pemaknaannya: Sebuah Ulasan Singkat”, Makalah Disampaikan dalam Workshop “Sensivitas Gender dalam Manajemen”, PSW IAIN Sunan Kalijaga, 28 September.

Sugiyono, 2010. Metode Penelitian Kualitatif dan $R \& D$. Bandung: Alfabet.

Suharto, Edi. 2005. Membangun Masyarakat, Memberdayakan Rakyat, Kajian Strategis Pembangunan Kesejahteraan Sosial dan Pekerja Sosial. Bandung: Refika Aditama.

Sumodiningrat, Gunawan. 2007. Pemberdayaan Masyarakat, Kajian Ringkas tentang Pembangunan Manusia Indonesia. Jakarta: Kompas Media Nusantara.

Sunartiningsih, Agnes. 2004. Pemberdayaan Masyarakat Desa Melalui Institusi Lokal. Yogyakarta: Aditya Media Bekerjasama dengan Jurusan Sosiatri Fisipol UGM. 
—. 2004.Strategi Pembedayaan Masyarakat. Yogyakarta: Aditya Media Kerjasama dengan Jurusan Sosiatri Fisipol UGM.

Syadzali, Munawir. 1993. Islam dan Tata Negara, Ajaran, Sejarah, dan Pemikiran. Jakarta: UI Press.

Tim Penyusun, Profil Kelembagaan dan Kegaitan Pondok Pesantren Al-Hikmah Sumberejo Karangmojo Gunung Kidul (Gunung Kidul: Pondok Pesantren Al-Hikmah, 2007).

Tim Penyusun, Profile Pondok Pesantren Tarbiyatun Nasyi'in Paculgowang Jombang (Jombang: Pondok Pesantren Tarbiyatun Nasyìin, 2009).

Tjahjono, Subur dan Prihadiyoko, Imam. "M. Syafi'I dan Obsesi Pluralisme” hasil wawancara dengan M. Syafi'I Anwar, Direktur Eksekutif International Centre for Islam and Pluralism (ICIP), dalam Harian Kompas, Sabtu, 30 Juli 2005.

Ubaidillah dkk. Pendidikan Kewargaan (Civic Education) Demokrasi, HAM, \& Masyarakat Madani. Jakarta: IAIN Syarif Hidayatullah Press, 2000.

Wrihatnolo, Randi R.dan Dwidjowijoto, Riant Nugroho. Manajemen Pemberdayaan - sebuah Pengantar dan Panduan untuk Pemberdayaan Masyarakat. Jakarta: Alec Media Komputindo, 2007.

\section{Informan :}

1. K.H. Harun Al-Rasyid (pengasuh Pesantren Al-Hikmah Gunung Kidul)

2. Ustadz Gus Hanung Hisbullah Hamda, SH (Pimpinan Pesantren Al-Hikmah Gunung Kidul Bidang Kurikulum Akademik/Pengajaran),

3. Ustadz Riyanto Abu Azzam (Pimpinan Pesantren Al-Hikmah Gunung Kidul Bidang Pengasuhan Santri)

4. Ustadz Widodo (Fasilitator Pesantren Al-Hikmah Gunung Kidul)

5. Ustadzah Sudarsiti (Fasilitator Pesantren Al-Hikmah Gunung Kidul)

6. KH. Abd. Aziz Manshur (Pengasuh dan sekaligus ketua Yayasan Pesantren Tarbiyatun Nasyi' in Paculgowang Jombang)

7. Ustadz Gus H. Adib Hamzawi, M.Ag. (Putra Pengasuh Pesantren Tarbiyatun Nasyi' in Paculgowang Jombang)

8. Ustadz Ahmad Ridwan (fasilitator Pesantren Tarbiyatun Nasyi' in Paculgowang Jombang)

9. Ustadz Lukman Hakim (fasilitator Pesantren Tarbiyatun Nasyi'in Paculgowang Jombang) 
10. Ustadzah Tatik Masrurah (Fasilitator Pesantren Tarbiyatun Nasyi'in Paculgowang Jombang)

11. Muqowim, M.Ag. (Direktur Puskadiabuma Pascasarjana UIN Sunan Kalijaga)

12. Drs. Ngadimin Chalimi, SE (Fasilitator Pusat dalam kegiatan pemberdayaan)

13. Ir. Nucky Menurwati (Fasilitator Pusat dalam kegiatan pemberdayaan)

14. Ir. Senthot Burhanuddin Ihsan (Fasilitator Pusat dalam kegiatan pemberdayaan) 